\title{
Effects of vitamin E, methylprednisolone and nedocromil sodium on healing of rats with experimentally created intraabdominal adhesions
}

\author{
Hasan Pinar ${ }^{1}$, Mürşit Dincer², Yavuz Selim Ilhan²
}

${ }^{1}$ Department of General Surgery, Antalya Medical Park Hospital, Antalya, Turkey ${ }^{2}$ Department of General Surgery, Firat University Hospital, Elazig, Turkey

Submitted: 4 May 2020

Accepted: 25 July 2020

Arch Med Sci Civil Dis 2020; 5: e48-e52

DOI: https://doi.org/10.5114/amscd.2020.100881

Copyright $\odot 2020$ Termedia \& Banach

\section{Abstract}

Introduction: Intraabdominal adhesions are a condition that can occur after many surgical procedures and may cause complications in a spectrum ranging from simple abdominal pain to ileus. For years, efforts have been made to prevent this complication. In this experimental study, the effects of methylprednisolone, vitamin $\mathrm{E}$ and nedocromil sodium on the improvement of intraabdominal adhesions in rats were investigated.

Material and methods: Twenty Wistar Albino rats weighing 280 to $330 \mathrm{~g}$ were divided into four equal groups. $5 \mathrm{ml}$ of $0.9 \% \mathrm{NaCl}$ was given to the control group, $5 \mathrm{ml}$ of methylprednisolone was given to group $2,5 \mathrm{ml}$ of vitamin E to group 3 and $5 \mathrm{ml}$ of nedocromil sodium to group 4 were given intraabdominally. On the $14^{\text {th }}$ postoperative day, all rats were sacrificed and re-laparotomy was performed. Intraabdominal adhesions were scored according to the Nair classification.

Results: When the groups were compared dyadically, the difference between group 1 and group 2 was found to be statistically significant $(p=0.011)$. The difference between group 1 and group 3 was statistically significant ( $p=$ 0.011 ). The difference between group 1 and group 4 was statistically significant $(p=0.007)$. There was no statistically significant difference between group 2 and group 3, and group 2 and group 4, and group 3 and group 4 $(p<0.05)$.

Conclusions: As a result, methylprednisolone, vitamin E and nedocromil sodium have been shown to have a healing effect on adhesions.

Key words: vitamin E, methylprednisolone, intraabdominal adhesion, nedocromil sodium.

\section{Introduction}

Abdominal and pelvic adhesions are the pathological structures between the peritoneal and pelvic cavity surfaces during the healing of peritoneal surface defects by scar formation. These ligaments may range from a thin connective tissue band to a thick, fibrosis or direct connection between two organ surfaces. Typically, adhesions occur between normal tissues that are in contact with areas that cannot be covered by normal mesothelium, such as on the injured peritoneal surface [1, 2].

Intraabdominal adhesions are most commonly secondary to abdominal operations, and although in many patients intraabdominal adhesions

\author{
Corresponding author: \\ Mürşit Dincer \\ Firat University Hospital \\ Elazig, Turkey \\ Phone: +905446422820 \\ E-mail: drmursitdincer@ \\ gmail.com
}


are asymptomatic, they may cause serious complications with an increased risk of small intestine obstruction, fistula development, chronic abdominopelvic pain, infertility, ureteral obstruction and prolonged operation time, postoperative bleeding, and increased intestine perforation [3-9].

\section{Material and methods}

In this study, 20 Wistar Albino female rats weighing between 280 and $330 \mathrm{~g}$ were used after obtaining the approval of the ethics committee. The experiments were carried out in a laboratory with temperature and humidity control, $12 \mathrm{~h}$ light and $12 \mathrm{~h}$ dark cycle. All subjects were fed with the same standard feed and city water supply. The rats were fasted for $12 \mathrm{~h}$ before the experiment. The experimental animals were separated into randomized groups which consisted of 5 rats each.

- group $1(n=5)$ : control group, intraabdominal $5 \mathrm{ml}$ of $0.9 \% \mathrm{NaCl}$ administered group,

- group $2(n=5)$ : methylprednisolone group, intrabdominal $5 \mathrm{ml}$ methylprednisolone administered group,

- group $3(n=5)$ : vitamin E group, intraabdominal $5 \mathrm{ml}$ vitamin $\mathrm{E}$ administered group,

- group $4(n=5)$ : nedocromil sodium group, intraabdominal $5 \mathrm{ml}$ nedocromil sodium administered group.

Subjects were anesthetized with intramuscular $5 \mathrm{mg} / \mathrm{kg}$ xylazine hydrochloride (Alfazyne 2\%, Alfasan - $20 \mathrm{mg} / \mathrm{ml}$ ) and $30 \mathrm{mg} / \mathrm{kg}$ ketamine hydrochloride (Ketalar - $50 \mathrm{mg} / \mathrm{ml}$ ). Following anesthesia, the subjects were positioned supine on the surgical table and fixed with a patch on the four extremities. Surgery was performed under clean but non-sterile conditions. After the anterior wall of the abdomen was shaved with an electric razor, the work area was cleaned with povidone-iodine. Laparotomy was performed in the midline with about a $40 \mathrm{~mm}$ incision. The trauma to the antimesenteric face of the cecum was traumatized

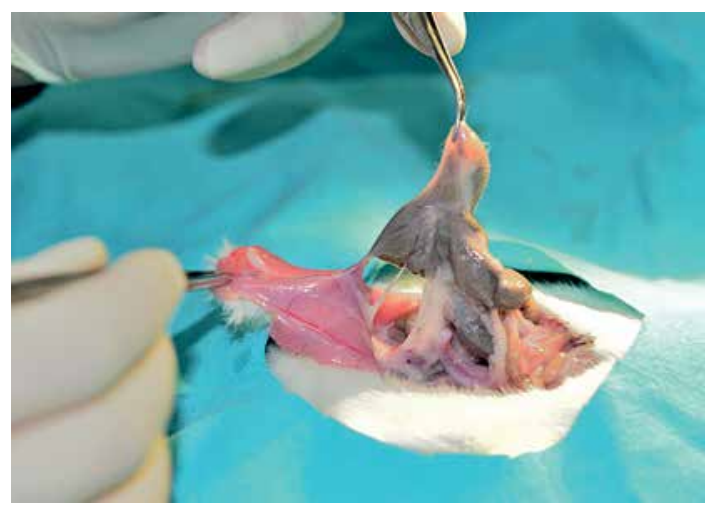

Figure 1. Adhesion image of rat in control group and placed again in the anatomic location of the abdomen. $5 \mathrm{ml}$ of $0.9 \% \mathrm{NaCl}$ was given to the control group, $5 \mathrm{ml}$ of methylprednisolone was given to group 2 rats, $5 \mathrm{ml}$ of vitamin $\mathrm{E}$ was given to group 3 rats and $5 \mathrm{ml}$ of nedocromil sodium was given to group 4 rats intraabdominally. The fascia 2/0 PDS was then closed with skin 3/0 silk. Animals were awakened and each group was placed in a separate cage. In the postoperative period, all animals were administered with analgesia by drinking water with paracetamol for 12-hour intervals. On the $14^{\text {th }}$ day of the operations, rats were sacrificed by carbon dioxide gas and relaparotomy was performed and a third person examined the adhesions in the abdomen. Intra-abdominal adhesions were scored according to the Nair classification.

\section{Statistical analysis}

The statistical evaluation of the data was performed using the SPSS 14 software. The significance of the difference between the groups was compared with the Mann-Whitney $U$ and KruskalWallis tests. The error level was accepted as 0.05.

\section{Results}

A total of 20 rats with 5 rats in each group were used in the experiment. During the study, no subjects were lost. None of the rats developed a wound infection. When the scores of the groups were compared, the difference between the groups was found to be statistically significant $(p<0.05)$. When the groups were compared statistically, the difference between group 1 and group 2 was found to be statistically significant $(p=$ 0.011 ). The difference between group 1 and group 3 was statistically significant $(p=0.011)$. The difference between group 1 and group 4 was statistically significant $(p=0.007)$. There was no statistically significant difference between group 2 and group 3, and group 2 and group 4, and group 3 and group $4(p<0.05)$ (Figures $1-4$, Table I).

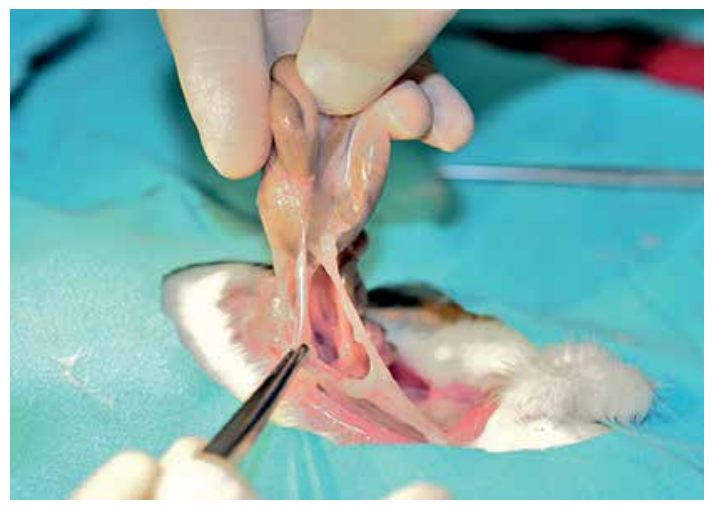

Figure 2. Adhesion image of rat in methylprednisolone group 


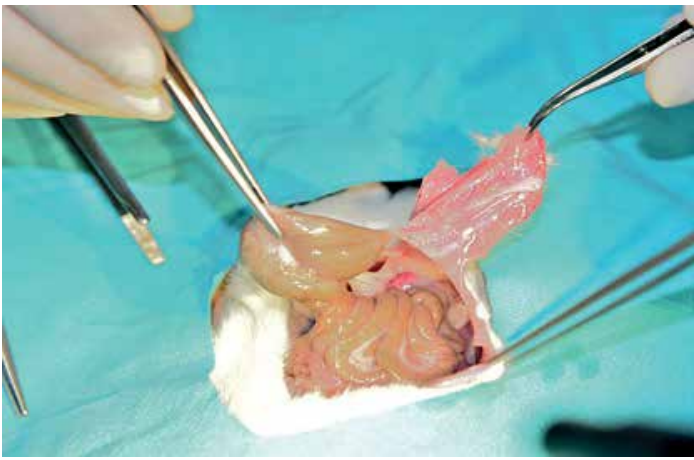

Figure 3. Adhesion image of rat in vitamin E group

Table I. Nair's intraabdominal adhesions score in each group

\begin{tabular}{|lcc|}
\hline Group & Minimum & Maximum \\
\hline 1 & 1.00 & 2.00 \\
\hline 2 & 0.00 & 1.00 \\
\hline 3 & 0.00 & 1.00 \\
\hline 4 & 0.00 & 1.00 \\
\hline
\end{tabular}

\section{Discussion}

Postoperative intraabdominal adhesions are an important cause of long-term morbidity and therefore there have been many studies on the prevention of adhesions in the scientific literature. Postoperative peritoneal adhesions occur as a result of damage to any single-layer mesothelial cells (mechanical, ischemic, chemical, infective, inflammatory, etc.) that form the peritoneum. Fibrin-rich exudation occurs in the damaged area. Fibrin forms bands between other peritoneal surfaces that come into contact with this area. Fibrin bands and the hyaluronic acid-rich matrix that fills the gap between them provide a very suitable environment for collagen synthesis. Real adhesions occur by synthesis of collagen [10-14]. Abdominal adhesions can cause chronic pain, intestinal obstruction, fistulas, and infertility. For these reasons, patients are treated as outpatients or are hospitalized and some patients have to be operated on again [15]. Apart from the additional morbidities brought by the patients, the financial burden on the economies of the country is also important. A method to prevent intraabdominal adhesion formation will eliminate the reoperation and the morbidity and financial burden associated with it [16]. In a study conducted by Beart in Los Angeles, the USA of 2645 autopsy records, incisions due to abdominal surgery were detected in $32 \%$ of the patients who underwent autopsy [17]. According to this study, approximately one-third of the adult population can be said to be at risk of intraabdom-

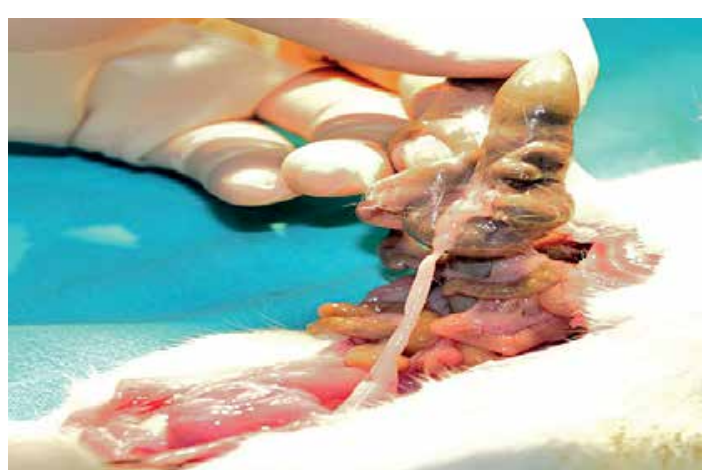

Figure 4. Adhesion image of rat in Nedocromil sodium group

inal adhesions. Although intraabdominal adhesions are usually asymptomatic, even a low rate of morbidity in such a large population will result in a very serious surgical workload and cost.

Several techniques, materials, and agents have been tried to prevent adhesions: various surgical methods, minimally invasive and laparoscopic techniques, pharmacological agents targeting the inflammatory response and/or fibrin formation after mesothelial cell trauma, liquids, gels, and solids that form a mechanical barrier between mesothelial surfaces. Although useful techniques or agents were found, no complete success was achieved and the results were not reflected in surgical practice except adhesion barriers [18-20]. It is recommended to give importance to medical prophylaxis in the prevention of postoperative peritoneal adhesions. The success of medical prophylaxis lies in the reduction of fibrinous exudation and inflammatory reaction, inhibition of coagulation, stimulation of fibrinolytic activity, inhibition of fibroblastic proliferation, and mechanical separation of serosal surfaces [11, 21-24]. Steroid anti-inflammatory drugs block the formation of inflammatory mediators such as prostaglandin, prostacyclin, thromboxane, and leukotriene, which are formed in the catalytic process of lipoxygenase and cyclooxygenase enzymes in the inflammatory process, the first step of adhesion development, called eicosanoids. Due to these properties, steroids are used to inhibit inflammatory reactions in clinics, to eliminate the effects of inflammation mediators and to prevent the proliferation of fibroblasts [11, 18, 25-30]. They can prevent adhesion development because of these properties.

Methylprednisolone is one of the steroidal anti-inflammatory drugs, which blocks the initiation of peritoneal adhesion events by blocking the enzyme phospholipase, which mediates the release of inflammation mediators during serosal destruction [25-28, 31, 32].

Kappas et al. applied hydrocortisone sodium succinate at a dose of $50 \mathrm{mg} / \mathrm{kg}$ in rats and de- 
termined that adhesion developed in 6 of the 20 rats given hydrocortisone [27]. Avşar et al. detected that antihistaminic (diphenhydramine $\mathrm{HCl}$ ) and steroids (methylprednisolone) alone and when used in combination with peritoneal adhesion stops the formation of adhesion in rats by preventing the occurrence of inflammation [21]. Alkan et al. applied $15 \mathrm{mg} / \mathrm{kg}$ methylprednisolone to rats experimentally induced with adhesions and found that adhesion development was significantly lower than in the control group [33]. In a study conducted by Küçüközkan et al. it was observed that the combination of saline and sodium cromoglycate administered intraperitoneally decreases pelvic adhesions [34]. When dexamethasone was added to this combination, it was found that adhesions decreased significantly, but since steroids were not used alone in this study, it is not possible to make a definitive interpretation of the efficacy of the steroid alone. In a study of Kırkak et al. with different doses of methylprednisolone, no difference was found between high and low dose methylprednisolone in terms of healing of adhesions, and fewer adhesions were observed than in the control group [35]. In this study, methylprednisolone, which is a steroid derivative, was used and the probability of peritoneal adhesion was significantly lower than in the control group. This result is similar to most of the previous studies done.

Vitamin E, a fat-soluble vitamin, has been argued to play an important role in maintaining cell integrity. In addition, it is suggested that vitamin $\mathrm{E}$ protects the cell membrane against its free oxidizing effects such as superoxide, peroxide and hydroxyl radicals, and this feature plays a role in preventing or reducing peritoneal adhesions. Kagoma et al. suggest that vitamin $E$ reduces thromboplastin and fibrin formation by inhibiting platelet aggregation. These researchers reported the peritoneal adhesion rate in the series' control group as $95 \%$ and $58 \%$ in the vitamin group [36]. According to Ellis, fibrins play an important role in the first stage of intraperitoneal adhesion formation. Vitamin E inhibits thromboplastin and fibrin production by inhibiting platelet aggregation and thrombus formation [11]. Yetgin et al. used vitamin $E$ and human amniotic membranes in their studies and they used both agents individually and together [37]. As a result, they found that both vitamin $\mathrm{E}$ and human amniotic membrane were effective in preventing intraperitoneal adhesions but they did not have a synergistic effect. In the study of Corrales et al., vitamin E was compared with carboxymethylcellulose in the prevention of intraperitoneal adhesions and was found to be as effective as carboxymethylcellulose [38]. In the De la Portilla et al. study, vitamin E was administered intraperitoneally and intramuscularly and it was observed that the administration of vitamin $\mathrm{E}$ by intraperitoneal administration decreased the adhesion development, but the same effect could not be obtained by intramuscular administration [39]. In this study, vitamin E was administered intraperitoneally and it was found that the rate of adhesion development in rats treated with vitamin E was significantly lower than in the control group. The results are similar to a few previous studies conducted on this subject.

Nedocromil sodium blocks the chlorine channels in many cells such as mast cells, epithelial cells and neurons [40]. In the Liebman et al. study, nedocromil was compared with sodium saline and was found to be effective in preventing postoperative peritoneal adhesions [6]. In the study of Rasti et al. nedocromil sodium and diphenhydramine $\mathrm{HCl}$ were compared in terms of preventing peritoneal adhesions, and the study showed that nedocromil sodium is more effective in the prevention of adhesions than both the control group and the diphenhydramine $\mathrm{HCl}$ group [41]. In this study, the rate of postoperative adhesion in the nedocromil sodium group was significantly lower than in the control group as well. This result is similar to two previous studies conducted. However, there was no difference between methylprednisolone and vitamin E groups.

As a result of this study, three of the agents that were thought to have a positive effect on the prevention of postoperative peritoneal adhesions, methylprednisolone, vitamin $\mathrm{E}$ and nedocromil sodium, were found to have healing effects on adhesions. However, none of these three agents was found to be superior to the others.

There are some limitations of this study. The small number of subjects in the groups and the examination of the early postoperative adhesions are limitations of this study. However, we believe that this study will contribute to the literature because there is no study on adhesion with these three agents.

In conclusion, we believe that methylprednisolone, vitamin $\mathrm{E}$ and nedocromil sodium are effective in preventing peritoneal adhesions by using different mechanisms and can be used in clinical practice. These three agents could not be found to have any superiority to each other. However, we believe that it is necessary to obtain more information about these agents by performing different experimental studies using different doses of different agents, and of course, we believe that clinical studies should be done to support these findings, and only this way do we believe that these agents can be used on humans.

\section{Conflict of interest}

The authors declare no conflict of interest. 
References

1. Tittel A, Treutner KH, Titkova S, et al. New adhesion formation after laparoscopic and conventional adhesiolysis. Surg Endosc 2001; 15: 44-6.

2. Cittadini E, Orland F, Benigno M. Pelvic adhesions and infertility: classification, prevention and therapy. Acta Eur Fertil 1982; 13: 105-11.

3. Müller SA, Treutner KH, Tietze L, et al. J Surg Res 2001; 96: 68-74.

4. Costain DJ, Kennedy R, Ciona C, et al. Prevention of postsurgical adhesions with N,O-carboxymethyl chitosan: examination of the most efficacious preparation and the effect of N,O-carboxymethyl chitosan on postsurgical healing. Surgery 1997; 121: 314-9.

5. Saed GH, Munkarah AR, Diamond MP. Cyclooxygenase-2 expressed in humanibroblasts isolated from in traperitoneal adhesions but not from normal peritoneal tissues. Fertil Steril 2003; 79: 1404-8.

6. Liebman SM, Langer JC, Marshall JS, Collins SM. Role of mast cells in peritoneal adhesion formation. Am J Surg 1993; 165: 127-30.

7. Vrijland WW, Tseng LNL, Eijkman HJM, et al. Fewer intraperitoneal adhesions with use of hyaluronic acid-carboxymethylcellulose membrane. Ann Surg 2002; 235: 193-9.

8. Erdener A, Çetinkursun S, DIhan H, Ulman D. Postoperatif intraperitoneal yapısıklıkların önlenmesinde $E$ vitamininin yeri. Ulusal Cerrahi Dergisi 1989; 5: 29-31.

9. Canbaz MA, Üstün C, Koçak D, Yanık FF. The comparsion of gonadotropinreleasing hormone agonist therapy and intraperitoneal Ringer's lactate solution in prevention of postopertive adhesion formation in rat medels. Obstet Gynecol 1999; 82: 219-22.

10. Menzies D, Ellis H. Intestinal obstruction from adhesions; how big is the problem? Ann R Coll Surg 1990; 72: 60-3.

11. Ellis $\mathrm{H}$. The causes and prevention of intestinal adhesions. Br J Surg 1982; 69: 241-3.

12. Senthilkumar MP, Dreyer JS. Peritoneal adhesions: pathogenesis, assessment and effects. Trop Gastroenterol 2006; 27: 11-8.

13. Holmdahl L, Risberg B. Adhesions: prevention and complications in general surgery. Eur J Surg 1997; 163: 169-74.

14. Davey AK, Maher PJ. Surgical adhesions: a timely update, a great challenge for the future. J Minim Invasive Gynecol 2007; 14: 15-22.

15. Alimoğlu O, Akçakaya A, Sahin M, et al. Prevention of adhesion formation following repair of abdominal wall defects with prosthetic materials. Hepatogastroenterology 2003; 50: 725-8.

16. Conze J, Junge $K$, Klinge $U$, et al. Intraabdominal adhesion formation of polypropilen mesh. Surg Endosc 2005; 19: 798-803.

17. Beart RW Jr. Multidisciplinary management of patients with advanced rectal cancer. Clin Cancer Res 2007; 13: 6890-3.

18. Liakakos T, Thomakos N, Fine PM, et al. Peritoneal adesions; etiology, pathophysiology, and clinical significance. Dig Surg 2001; 18: 260-73.

19. El-Mowafi DM, Diamond MP. Are pelvic adhesions preventable? Surg Technol Int 2003; 11: 222-35.

20. Attard JA, MacLean AR. Adhesive small bowel obstruction: epidemiology, biology and prevention. Can J Surg 2007; 50: 291-300.

21. Avsar FM, Sahin M, Aksoy F, et al. Effect of diphenhydramine $\mathrm{HCl}$ and methylprednisolone in the prevention of abdominal adhesion. Am J Surg 2001; 181: 512-5.
22. Baxter GM, Broome TE, Moore JN. Abdomınal adhesıons after small intestinal surgery in the horse. Vet Surg 1989; 18: 409-14.

23. Yalın R. Karın içi ameliyatlarından sonra oluşan yapışıklıklar ve önlenmesi. Kolon ve Rektum Hastalık1arı Dergisi 1997; 7: 12-7.

24. Durmus AS, Han MC. Effect of bovine amniotic fluid on intraabdominal adhesıons. Indian Vet J 2006; 83: 621-3.

25. Di Zerega GS. Contemporary adhesions prevention. Fertil Steril 1994; 61: 219-35.

26. Desimone JM, Meguid MM, Kurzer M, Westerven J. Indomethacin decreases carregenan induced peritoneal adhesions. Surgery 1988; 104: 785-95.

27. Kappas AM, Barsoum GH, Ortız JB, Keighley MRB. Prevention of peritoneal adhesions in rabbits with verapamil, hydyrocortisone Sodıum succinate, and phosphatidylcholine. Eur I Surg 1992; 158: 33-5.

28. Taçyıldız IH, Aban M, Şahin H, et al. Deneysel peritonit modelinde dısodyum kromoglıkat ve piroksikamın karın içi yapışıkıklara etkisi. Ulusal Travma Dergisi 1998; 4 230-4.

29. Yılmazlar T, Kaya E, Gürpınar E, Emiroğlu H. Efficacy of tenoxicam on intraabdomınal adhesıon prevention in a ral model. J Int Med Aes 1996; 24: 352-7.

30. Dijkstra FA, Niuwenhuijzen M, Reiinen MMPJ, Goor H. Recent clinial developments in pathophysiology, diagnosis and treatment of intraabdominal adhesions. Scand J Gastroenterol 2000; 35: 52-9.

31. Holtz G. Prevention of postoperative adhesions. J Reprod Med 1980; 24: 141-6.

32. Wallach EE, Holtz G. Prevention and management of peritoneal adhesions. Fertil Steril 1984; 41: 497-507.

33. Alkan F, Koç Y, Çelik I, et al. Tavşanlarda peritoneal adezyonların önlenmesinde metilprednizolon ve dimetilsulfoksitin etkilerinin araştırılması. Vet Bil Derg 2007; 2: 73-9.

34. Kucukozkan T, Ersoy B, Uygur D, Gundogdu C. Prevention of adhesions by sodium chromoglycate, dexamethasone, and aprotinin after pelvic surgery. ANZ J Surg 2004; 74: 1111-5.

35. Kırkak T, Uysal E, Korun N. Karın içi yapışıklıkların önlenmesinde metilprednizolonun farklı dozlarının etkinliğinin incelenmesi. Ulus Travma Acil Cerrahi Derg 2008; 14: 188-191.

36. Kagoma P, Burger NS, Seifter E, et al. The effect of vitamin $\mathrm{E}$ an experimentally induced peritoneal adhesions on mice. Arch Surg 1982; 117: 1321-4.

37. Yetgin G, Uludağ $M$, Citgez $B$, et al. Prevention of peritoneal adhesions by intraperitoneal administration of vitamin $\mathrm{E}$ and human amniotik membrane. Int I Surg 2009; 7: 561-5.

38. Corrales F, Corrales M, Schirmer CC. Preventing intraperitoneal adhesions with vitamin $\mathrm{E}$ and sodium hyaluronate/carboxymethylcellulose: a comparative study in rats. Acta Cir Bras 2008; 23: 36-41.

39. de la Portilla F, Ynfante I, Bejarano D, et al. Prevention of peritoneal adhesions by intraperitoneal administration of vitamin E: an experimental study in rats. Dis Colon Rectum 2004; 47: 2157-61.

40. Devalia JL, Rusznak C, Abdelaziz MM, Davies RJ. Nedocromil sodium and airway inflammation in vivo and in vitro. J Allergy Clin Immunol 1996; 98: 551-7.

41. Rasti M, Parvaresh E, Tavajoh S, Talaei M. The comparison of diphenhydramine $\mathrm{HCl}$ and Nedocromil sodium in prevention of abdominal postoperative adhesion formation in rat models: an experimental study. Int J Surg 2007; 5: 384-7. 